\title{
Comparative study on the intestine of Schilbe mystus and Labeo niloticus in correlation with their feeding habits
}

\author{
Fawzy I. Amer; Suzan A. A. Naguib and Fawzia A. Abd El Ghafar \\ Department of Zoology, Faculty of Science, Ain Shams University
}

\begin{abstract}
The present investigation aims to illustrate the morphological, histological and ultrastructural differences in the intestine of a carnivorous fish, Schilbe mystus and a herbivorous fish, Labeo niloticus, in correlation with their feeding habits. The histological examination of the mucosa of the intestine of both studied species revealed that it is built up of a simple columnar epithelium that contains goblet cells. Though these, are generally more numerous in the intestine of Schilbe mystus than in that of Labeo niloticus. The ultrastructural investigation of the mucosa of the duodenum and ileum of Schilbe mystus revealed that the enterocytes are tall columnar cells and possess well-developed microvilli, numerous mitochondria, microtubules and numerous lipid droplets. The ultrastructural examination of the mucosa of the ileum of Labeo niloticus revealed that the enterocytes are tall columnar and possess well-developed microvilli, numerous mitochondria, microtubules, a few endocytotic channels and aggregated chylomicrons. The enterocytes of the rectum of both studied species are tall columnar and are characterized by the presence of short and wellspaced microvilli, a well-developed vesiculotubular system, numerous microtubules and mitochondria. In addition, the rectal enterocytes of Schilbe mystus contain endocytotic vesicles. The intestinal muscularis of both studied species is well-developed and built up of unstriated muscle fibres, which are arranged into two layers: an inner circular layer and an outer longitudinal one. The rectal muscularis of both studied species is thicker than that of the rest of the intestine.
\end{abstract}

Key words: Schilbe mystus, Labeo niloticus, feeding habits, intestine light and ultrastructure

\section{INTRODUCTION}

Al-Hussaini (1947) stated that the relative gut length of some marine teleosts is correlated to the diet in a consistent manner. He found that the herbivores possess the longest relative gut length, followed by omnivores, carnivores and finally planktivores with the shortest intestine. Elliott and Bellwood (2003) also postulated the same concept in three families of coral reef fishes. Nevertheless, they stated that the corallivores and omnivores typically possess the longest intestine, then herbivores and finally carnivores with the shortest intestine. 
Yamamoto (1966), in Salmo irideus and Carassius auratus; Kayanja et al. (1975), in Tilapia grahami; Stroband (1977), in the juvenile of Ctenopharyngodon idella; Noaillac-Depeyre and Gas (1979), in Perca fluviatilis, and Anderson (1986), in Girella tricuspidata found that the height of the microvilli of the teleost enterocytes is gradually decreased from the anterior to the posterior parts of the intestine.

Kapoor et al. (1975) and Grau et al. (1992) stated that the main features of the carnivorous fish digestive tract are the presence of large stomach and short intestine.

Jilek (1979) stated that the intestinal mucosa of the filter feeder teleost, Dorosoma cepedianum, consists of two basic cell types, the goblet and columnar cells. He also stated that the intestine has a thin muscularis mucosa and the muscularis consists of two layers of the smooth type, an outer longitudinal and an inner circular muscle layers. Ünal et al. (2001) also postulated the same concept in Chalcalburnus tarichi.

Watanabe (1981), in some teleosts, and Anderson (1986) in Girella tricuspidata, elucidated that the intestine can be divided into an anterior lipidabsorbing region and a posterior region for absorbing macromolecular proteins and soluble nutrients.

MacDonald (1987), in the juvenile and adult Drover sole, Solea solea, and Caceci and Hrubec (1989 \&1990), in the black mollie, Poecilia spp., stated that the apical microvilli characterize the epithelial cells of all regions of the gastro-intestinal tract.

Deplano et al. (1989) reported that the enterocytes of the proximal intestine of Dicentrarchus labrax contain two categories of lipids: the lipid granules or particles (chylomicrons) and free lipid droplets.

Grau et al. (1992) stated that the pyloric caeca of Seriola dumerili, which are located between the stomach and intestine, might be related to its feeding habit. In addition, they stated that the muscularis is formed of three muscular layers throughout the whole length of the intestine, whereas only two layers are found in most teleost species. The same authors explained that the increase of the smooth muscular sheet could be related to the increase of intestinal motility, which would optimize the intestinal absorption in the carnivorous fish with irregular intake of large quantities of food. They also noticed that the rectum displays a deeply infolded mucosa and its muscularis is twice as thick as the intestinal muscular layer, which would contribute to the expulsion of the undigested materials through the anus.

Kuperman and Kuz'mina (1994) stated that there is probably a link between the feeding habits of the teleost fish in general and the structure of the enterocyte brush border.

Tibbetts (1997) observed that the digestive system of the snub-nosed garfish, Arrhamphus sclerolepis krefftii, lacks many of the alimentary 
modifications common in the alimentary tract of the herbivorous fishes such as, the acidic stomach, long intestine and pyloric caeca.

Albrecht et al. (2001) in Leporinus friderici and Leporinus taeniofasciatus, and Cinar and Senol (2006), in Pseudophoxinus antalyae, reported that the digestive tract has a four-layered general structure namely: mucosa, submucosa, muscularis and serosa, while the muscularis mucosa is absent.

Petrinec et al. (2005) stated that the mucosubstances in the mucosa of the digestive tract of Esox lucius and Silurus glanis are involved in lubrication and protection processes of the mucosa against acidity and enzymatic actions.

\section{MATERIALS AND METHODS}

The freshwater Nile silver schilbeid catfish, Schilbe mystus (Linnaeus, 1758), (Order: Siluriformes, Family: Schilbeidae) and the freshwater Nile carp, Labeo niloticus (Forsskål, 1775), (Order: Cypriniformes, Family: Cyprinidae) were used in the present investigation.

\section{1- Collection of the Samples:}

The adult specimens of the silver schilbeid catfish, Schilbe mystus, ranging from $15-28 \mathrm{~cm}$ in length, and of the Nile carp, Labeo niloticus, ranging from $20-40 \mathrm{~cm}$ in length, were caught alive from the River Nile at different localities between Beni Suef and Giza. They were killed and dissected immediately in the field.

\section{2- Morphological, Histological and Ultrastructural Studies:}

Fresh adult specimens were carefully dissected to expose the digestive system. The gut length (LG) was measured as the distance from the oesophagus to the end of the rectum. The gut length was correlated with the standard length (LS) of the fish to obtain the relative gut length (RGL) of each species. Which is expressed by the following equation:

$$
\mathrm{RGL}=(\mathrm{LG}) .(\mathrm{LS})^{-1}
$$

Then, small pieces of each intestinal region of both studied species were fixed in aqueous or alcoholic Bouin's fluid for $24 \mathrm{hrs}$. After fixation and washing, dehydration was carried out in ascending grades of ethyl alcohol. The materials were then cleared in terpineol and were embedded in molten paraplast. Sections of 5-7 $\mu \mathrm{m}$ thick were cut and were stained with Harris' haematoxylin and counterstained with eosin. Some sections were stained with Periodic AcidSchiff reagent (PAS) and counterstained with haematoxylin to demonstrate the mucus-secreting cells. The sections were examined by a light microscope and measurements were carried out using the eyepiece micrometer, calibrated by the stage micrometer. Photomicrographs were made as required.

Small pieces of the different regions of the intestine, (the duodenum, ileum and rectum of Schilbe mystus and the ileum and rectum of Labeo niloticus) were immediately fixed in cold $3 \%$ glutaraldehyde solution in phosphate buffer ( $\mathrm{pH} 7.2$ to 7.4) or in a mixture of glutaraldehyde and 
formaldehyde for three hours to overnight at $4^{\circ} \mathrm{C}$, then immersed in the phosphate buffer for $24 \mathrm{hrs}$. The materials were then washed thoroughly with phosphate buffer at least for three times, 10 minutes each, with shaking. The materials were then post-fixed in $2 \%$ osmium tetroxide (OsO4) for $1 \mathrm{hr}$ in a dark place at $4^{\circ} \mathrm{C}$. Then the materials were washed with phosphate buffer three times, 10 minutes each. The materials were dehydrated in ascending series of ethyl alcohol (up to the absolute), 10 minutes each, at $4^{\circ} \mathrm{C}$. They were then cleared in pure propylene oxide for 15 minutes and transferred to a mixture of propylene oxide and epoxy resin.

Afterwards, the materials were infiltrated with pure epoxy resin for $4 \mathrm{hrs}$ and embedded in fresh epoxy resin at $60^{\circ} \mathrm{C}$ in an oven under vacuum.

Resin blocks were cut with the ultramicrotome into semithin sections ( $1 \mu \mathrm{m}$ thick) and stained with toluidine blue.The slides were examined with the light microscope to select the suitable areas for ultrathin sectioning. Silver to pale golden ultrathin sections ( $600 \AA$ in thickness) were mounted on copper grids. The sections were stained in darkness with $5 \%$ uranyle acetate and lead citrate according to Reynolds (1963). Finally, the grids were then examined with JOEL 1200 EX II electron microscope at the Electron Microscope Unit in the Central Laboratory, Faculty of Science, Ain Shams University and JOEL 100S electron microscope at the Electron Microscope Unit in the National Cancer Institute.

\section{1- Morphological Studies}

\section{RESULTS}

\section{A- Schilbe mystus:}

The intestine of Schilbe mystus is relatively short with few small coils or loops. Posterior to the pyloric sphincter, the intestine can be distinguished into three regions: the duodenum, ileum and rectum. There are no obvious constrictions between these three different regions of the intestine.

The duodenum is the most anterior portion of the intestine and is a wide, short and straight tube. The ileum consists of a coiled tube, whose coils are attached with each other by the mesenteries. The rectum consists of a straight tube, which opens posteriorly by the anus.

The gut length is short and the relative gut length varies from 1.4 to 2.3 $\mathrm{cm}$ (Table 1).

\section{B- Labeo niloticus:}

The intestine of Labeo niloticus occupies the greater part of the abdominal cavity and is formed of an extremely long and thin-walled tube. The intestine is distinguished into two regions: a proximal ileum and a distal rectum.

The ileum consists of a long, coiled thin-walled tube. The coils of the ileum are numerous, long and held together by the mesenteries, which possess scattered red patches of the spleen. These coils are arranged in the horizontal plane within the abdominal cavity. On the other hand, the rectum consists of a 
straight uncoiled tube, which opens by the anus. There is no visible marked line separating the two different regions of the intestine proper.

The gut is remarkably long and the relative gut length varies from 16.6 to $21.9 \mathrm{~cm}$ (Table 1).

Table (1): The standard length (LS), the gut length (LG) and the relative gut length (RGL), which equals (LG). (LS) ${ }^{-1}$, of Schilbe mystus and Labeo niloticus. (The total number of the specimens examined for each species $=10)$.

\begin{tabular}{|c|c|c|c|c|c|}
\hline \multicolumn{3}{|c|}{ Schilbe mystus } & \multicolumn{3}{c|}{ Labeo niloticus } \\
\hline LS (cm) & LG (cm) & RGL & LS (cm) & LG (cm) & RGL \\
\hline 13 & 20 & 1.5 & 27.5 & 455 & 16.6 \\
\hline 18 & 25.5 & 1.4 & 29 & 560 & 19.3 \\
\hline 18 & 27.5 & 1.5 & 30 & 545 & 18.2 \\
\hline 18 & 30 & 1.7 & 30 & 570 & 19.0 \\
\hline 19 & 43 & 2.3 & 31 & 596 & 19.2 \\
\hline 19.5 & 31 & 1.6 & 32 & 621 & 19.4 \\
\hline 21 & 32.5 & 1.6 & 32 & 590 & 18.4 \\
\hline 21.5 & 50 & 2.3 & 32 & 615 & 19.2 \\
\hline 22 & 30.5 & 1.4 & 32.5 & 610 & 18.8 \\
\hline 24 & 46 & 1.9 & 35 & 765 & 21.9 \\
\hline
\end{tabular}

\section{2- Histological Studies}

The intestinal wall of both studied species is constructed of the main four layers: the mucosa, submucosa, muscularis and serosa.

The lymphocytes are numerous and are scattered in the mucosal epithelium and the lamina propria of the whole intestine. They are easily distinguished by their scanty amount of cytoplasm and rounded centrally located nuclei.

\section{A-The intestine of Schilbe mystus}

\section{1- The duodenum:}

The duodenal wall will be described in details, then the description of the rest of the intestinal wall is focused on the structural differences.

\section{i- The mucosa:}

The mucosa of the duodenum is thrown up into long highly branched villi (Fig.1). These villi are covered with a simple columnar epithelium that contains numerous goblet cells (Fig. 2).

The columnar cells of the duodenal mucosa have the typical structure of the absorptive cells. They are tall columnar cells with a prominent brush border (Figs. 2 and 3). The columnar cells possess a finely granulated eosinophilic cytoplasm and oval nuclei, whose long axes are perpendicular to the extremely thin basement membrane. The nuclei are situated in the basal half of the cells at 
nearly the same levels (Fig. 3). The cytoplasm, especially the apical part, possesses numerous aggregations of lipid droplets (Fig. 4).

\section{The goblet cells:}

The goblet cells are pyriform in shape with two distinct parts: the apical swollen and the basal elongated parts. The apical swollen part contains secretory granules, while the basal elongated part contains an oval nucleus. The swollen part possesses a single pore on the luminal surface of the duodenal epithelium (Figs. 2 and 4).

\section{The lamina propria:}

The lamina propria consists of a loose connective tissue that lies beneath the mucosal epithelium and supports its villi (Figs. 2 and 3).

\section{ii- The submucosa}

The submucosa is an extremely thin layer of loose connective tissue, which is in continuation with that of the lamina propria (Figs. 2 and 3).

\section{iii- The muscularis}

The muscularis is thin and consists of unstriated muscle fibres arranged in two layers: an outer longitudinal and an inner circular muscle layers (Fig. 5).

\section{iv- The serosa}

The serosa consists of a simple squamous epithelium with flattened centrally located nuclei (Fig. 5).

\section{2- Ileum:}

\section{i- The mucosa}

The mucosa of the ileum is thrown up into numerous long simple villi (Fig. 6). The mucosa is lined by a simple columnar epithelium, which contains numerous goblet cells (Fig. 7). The columnar cells have the typical structure of the absorptive cells; they are tall columnar and have a prominent brush border. These columnar cells possess a highly vacuolated eosinophilic cytoplasm and oval basally located nuclei whose long axes are perpendicular to the extremely thin basement membrane. The cytoplasmic vacuoles are lipid aggregations, which are mainly concentrated in the apical cytoplasm (Fig. 7).

\section{iii- The muscularis}

The muscularis of the ileum is thin anteriorly, but is gradually increased in thickness posteriorly. The muscularis consists of unstriated muscle fibres arranged in two layers: an outer longitudinal layer and an inner circular one (Fig. 8).

\section{3- The rectum:}

\section{i- The mucosa}

The mucosa of the rectum is organized into numerous long simple villi (Fig. 9). The mucosa is built up of a simple columnar epithelium which contains numerous goblet cells. The columnar cells of the rectum are tall and have a prominent darkly stained brush border. These cells have a homogeneous finely granulated eosinophilic cytoplasm and oval nuclei, located in the basal half of 
the cells nearly at the same level. The long axes of the nuclei are perpendicular to the basement membrane (Fig. 10).

\section{iii- The muscularis}

The muscularis of the rectum is thick and well developed. The muscularis consists of unstriated muscle fibres arranged in two layers: an outer longitudinal and an inner circular muscle layers. The inner circular layer is more developed than the outer longitudinal one (Fig. 9).

\section{B - The intestine of Labeo niloticus:}

\section{1- The ileum:}

\section{i- The mucosa}

The mucosa of the ileum is thrown up into simple villi, which are long with tapering ends anteriorly and become shorter and broader posteriorly (Figs. 11 and 12). The mucosa consists of a simple columnar epithelium, which contains numerous goblet cells. The columnar cells have the typical structure of the absorptive cells; they are tall columnar and have a prominent brush border, which is less developed than that of the intestinal swelling. These columnar cells possess a homogeneous eosinophilic cytoplasm and oval nuclei, whose long axes are perpendicular to the basement membrane (Figs. 11and 13).

\section{iii- The muscularis}

The muscularis of the ileum consists of unstriated muscle fibres arranged in two layers: an outer longitudinal and an inner circular muscle layers (Figs. 11and 12).

\section{2- The rectum:}

\section{i- The mucosa}

The mucosa of the rectum is thrown up into simple and branched villi with broad ends (Fig. 14). The mucosa is lined by a simple columnar epithelium containing goblet cells. The columnar cells of the rectum are tall and have a prominent brush border, which is less developed than that of the intestinal swelling and ileum. The columnar cells have a homogeneous finely granulated eosinophilic cytoplasm and oval nuclei, whose long axes are perpendicular to the basement membrane (Fig. 15).

\section{iii- The muscularis}

The muscularis of the rectum is well developed and consists of unstriated muscle fibres arranged in two layers: an outer longitudinal and an inner circular muscle layers (Fig. 16).

\section{3- Ultrastructural Studies}

\section{a- The enterocytes of the duodenum}

The enterocytes of the duodenum are tall columnar cells (about $33 \mu \mathrm{m}$ in average height), which rest on the basement membrane. The apical cell membrane bears numerous regularly arranged cytoplasmic projections, the microvilli, which form the brush border. These microvilli are covered by the glycocalyx and the upper part of some of them is dense and forms spherical bleb, the capitulum. The mean length of the microvilli is about $2.4 \mu \mathrm{m}$ and mean 
diameter is about $0.12 \mu \mathrm{m}$. The apical cytoplasm, just below the microvilli, has no cellular organelles and forms the terminal web (Fig. 17).

The cells are heavily loaded with lipid droplets of variable sizes (the diameter varies from 0.7 to $3.8 \mu \mathrm{m}$ ). These droplets are rounded in shape and are scattered throughout the cell cytoplasm and sometimes coalesce with each other (Fig. 17).

The Golgi apparatus is formed of numerous parallel stacks and lies near the nucleus (Fig. 18).

The rough endoplasmic reticulum consists of numerous long parallel tubules, which are studded with numerous ribosomes (Fig. 19). On the other hand, the smooth endoplasmic reticulum is poorly developed. Numerous free ribosomes are scattered throughout the cell cytoplasm (Fig. 18).

The mitochondria are numerous, electron-dense, polymorphic (rounded, oval and elongated in shape) and are of variable sizes (the mean diameter is about $0.3 \mu \mathrm{m}$ and the mean long axis is about $1.3 \mu \mathrm{m}$ ). The inner mitochondrial membrane forms numerous lamellar cristae (Fig. 19). The mitochondria are accumulated mainly in two regions: the apical cytoplasm beneath the terminal web and the infranuclear region.

The enterocyte is characterized by the presence of numerous microtubules, which are scattered in the cell cytoplasm and run parallel to the long axis of the cell (Fig. 20). The mean diameter of these microtubules is about $0.02 \mu \mathrm{m}(22 \mathrm{~nm})$.

The nuclei of the enterocytes are oval in shape (the long axis is about $6 \mu \mathrm{m})$ and each one contains a prominent centrally located nucleolus. The nuclear envelope is a double membrane consisting of the outer and inner nuclear membranes that encompass the nucleoplasm. The nuclear pores are found at intervals in the nuclear envelope. The euchromatin is represented by the pale granular areas of the nucleoplasm. On the other hand, the heterochromatin is represented by small and dense granular patches scattered throughout the nucleoplasm and attached to the inner side of the inner nuclear membrane (Fig. 21).

The lateral cell membranes form smooth contact with the adjacent cells and lack interdigitations. The apical ends of these lateral walls of the adjacent cells join together by the junctional complexes (Fig. 17).

\section{b- The enterocytes of the ileum}

The enterocytes of the ileum are tall columnar cells (about $35 \mu \mathrm{m}$ in average height), which rest on the basement membrane. The apical cell membrane carries numerous, juxtaposed and regularly arranged cytoplasmic projections, the microvilli, which form the brush border (Fig. 22). These microvilli are covered by the glycocalyx and the upper part of some of them is dense and forms spherical bleb, the capitulum. The mean length of the microvilli is about $2 \mu \mathrm{m}$ and its mean diameter is about $0.09 \mu \mathrm{m}$. The apical cytoplasm, 
just below the microvilli, has no cellular organelles and forms the terminal web (Fig. 23).

The cell cytoplasm contains numerous lipid droplets, which are mainly rounded in shape with variable sizes (the diameter varies from 0.5 to $2.7 \mu \mathrm{m}$ ). These lipid droplets are scattered throughout the cell cytoplasm, especially in the supranuclear region (Fig. 22).

The Golgi apparatus is found in a supranuclear position and is formed of numerous parallel stacks (Fig. 24).

The endoplasmic reticulum is well developed and consists of two types: the rough and smooth endoplasmic reticula. The rough endoplasmic reticulum consists of tubules and cisternae, which are studded with numerous ribosomes (Fig. 23). On the other hand, the smooth endoplasmic reticulum consists of smooth cisternae. The free ribosomes are abundant and scattered throughout the cell cytoplasm (Fig. 24).

The mitochondria are numerous, electron-dense, polymorphic (rounded, oval, elongated and ring-like in shape) and with variable sizes (the mean diameter is about $0.3 \mu \mathrm{m}$ and the mean long axis is about $1.3 \mu \mathrm{m})$. The inner mitochondrial membrane forms numerous lamellar cristae (Fig. 25). The mitochondria are accumulated mainly in two regions: the apical cytoplasm beneath the terminal web and the infranuclear region.

The enterocytes are characterized by the presence of numerous microtubules, which are scattered in the cell cytoplasm and run parallel to the long axis of the cell. The mean diameter of these microtubules is about $0.02 \mu \mathrm{m}$ $(23 \mathrm{~nm})$. These microtubules are seen connected to the lateral cell membranes (Fig. 26)

The nucleus is oval in shape (the long axis is about $6 \mu \mathrm{m}$ ) and possesses a prominent nucleolus (Fig. 22). The nuclear envelope is a double membrane consisting of the outer and inner nuclear membranes that encompass the nucleoplasm. The nuclear pores are found at intervals in the nuclear envelope. The euchromatin is represented by the pale granular areas of the nucleoplasm, whereas the heterochromatin is represented by small dark granular patches scattered throughout the nucleoplasm and attached to the inner side of the inner nuclear membrane (Fig. 26).

The lateral cell membranes form smooth contacts with the adjacent cells and lack interdigitations. The apical ends of these lateral walls of the adjacent cells join together by the junctional complexes (Fig. 23).

\section{c- The enterocytes of the rectum}

The enterocytes of the rectum are tall columnar cells (about $35 \mu \mathrm{m}$ in average height), which rest on the basement membrane. The apical cell membrane carries numerous short, well-spaced and regularly arranged cytoplasmic projections, the microvilli, which form the brush border (Fig. 27). These microvilli are covered by a prominent glycocalyx and the upper part of some of them is dense and forms spherical bleb, the capitulum. The mean length 
of the microvilli is about $0.5 \mu \mathrm{m}$ and their mean diameter is about $0.1 \mu \mathrm{m}$. The terminal web contains a few number of the endocytotic vesicles (Fig. 28). The lipid droplets are totally absent from the cell cytoplasm.

The apical cell cytoplasm, just beneath the terminal web, contains the vesiculotubular system, which consists of numerous oval or rounded vesicles with electron-dense outlines (Fig. 28). These vesicles have variable sizes (the long axis varies from 0.1 to $0.4 \mu \mathrm{m}$ ). A few number of these vesicles are scattered throughout the cell cytoplasm.

The Golgi apparatus is found in a supranuclear position and is formed of one or more sets of numerous parallel stacks and small vesicles (Fig. 29).

The endoplasmic reticulum consists of two types: the rough and smooth endoplasmic reticula. The rough endoplasmic reticulum is well developed and consists of long tubules, which are studded with numerous ribosomes. On the other hand, the smooth endoplasmic reticulum consists of a few number of smooth cisternae. The free ribosomes are abundant and are scattered throughout the cell cytoplasm (Fig. 29).

The mitochondria are numerous, electron-dense, rounded or elongated in shape and are of variable sizes (the mean diameter is about $0.3 \mu \mathrm{m}$ and the mean long axis is about $1.1 \mu \mathrm{m}$ ). The inner mitochondrial membrane forms numerous lamellar cristae (Fig. 30). The mitochondria are accumulated mainly in two regions: the supranuclear, just beneath the vesicles zone, and infranuclear regions.

The cytoplasm of the enterocyte is characterized by the presence of numerous lysosomes, which are surrounded by distinct membranes (Fig. 30).

The enterocytes are characterized by the presence of numerous microtubules and microfilaments, which are scattered in the cell cytoplasm. The microtubules run parallel to the long axis of the cell, with the mean diameter about $0.02 \mu \mathrm{m}(22 \mathrm{~nm})$ (Fig. 30). The microfilaments are scattered throughout the cell cytoplasm and even in the region of the terminal web (Fig. 28).

The nuclei of the enterocytes are large, oval in shape (the long axis is about $8 \mu \mathrm{m}$ ) and each one contains a prominent centrally located nucleolus (Fig. 27). The nuclear envelope is a double membrane consisting of the outer and inner nuclear membranes that encompass the nucleoplasm. The chromatin consists mainly of the euchromatin, which is represented by the pale granular areas of the nucleoplasm, and the heterochromatin which is poorly developed and is represented by the small dark granular areas (Fig. 29).

The lateral cell membranes form smooth contacts with the adjacent cells and lack interdigitations. The apical ends of these lateral walls of the adjacent cells join together by the junctional complexes (Fig. 27).

\section{a- The enterocytes of the ileum}

The enterocytes are tall columnar cells (about $54 \mu \mathrm{m}$ in average height), which rest on the basement membrane. The apical cell membrane bears numerous and regularly arranged cytoplasmic projections, the microvilli, which 
form the brush border (Fig. 31). These microvilli are covered by the glycocalyx and the upper part of some of them is dense and forms spherical bleb, the capitulum. The mean length of the microvilli is about $1.3 \mu \mathrm{m}$ and their mean diameter is about $0.14 \mu \mathrm{m}$. The apical cytoplasm, just below the microvilli, has no cellular organelles and forms the terminal web. Invaginations of the apical cell membrane are frequently seen among the microvilli, forming the endocytotic channels (Fig. 32).

The enterocytes cytoplasm and the intercellular spaces contain small lipid chylomicrons (Fig. 33).

The Golgi apparatus is located near the nucleus and is formed of one or two sets of parallel stacks and vesicles (Fig. 33).

The rough endoplasmic reticulum is well developed and consists of numerous, long and parallel tubules (Fig. 33). On the other hand, the smooth endoplasmic reticulum consists of a few short smooth tubules and cisternae (Fig. 32). The free ribosomes are abundant and are scattered throughout the cell cytoplasm (Fig. 33).

The mitochondria are numerous, electron-dense, polymorphic (rounded, oval, elongated and ring-like in shape) and are of variable sizes (the mean diameter is about $0.3 \mu \mathrm{m}$ and the mean long axis is about $1.1 \mu \mathrm{m}$ ). The inner mitochondrial membrane forms numerous lamellar cristae. They are mainly aggregated at the basal part of the cell (Fig. 34).

The cytoplasm is characterized by the presence of numerous lysosomes, which are surrounded by distinct membranes (Fig. 31).

The enterocyte contains numerous microtubules, which are scattered in the cytoplasm and run parallel to the lateral cell membranes. The microtubules are usually seen joining the lateral cell membranes (Fig. 33). The mean diameter of these microtubules is about $0.025 \mu \mathrm{m}(25 \mathrm{~nm})$.

The nuclei are large, oval in shape (the long axis is about $8.5 \mu \mathrm{m}$ ) and each one contains a prominent centrally located nucleolus (Fig. 31). The nuclear envelope is a double membrane consisting of the outer and inner nuclear membranes that encompass the nucleoplasm. The chromatin is represented by the euchromatin, which is formed of the pale granular areas of the nucleoplasm and the heterochromatin which is represented by the dark granular areas of the nucleoplasm (Fig. 35).

The lateral cell membranes form smooth contacts with the adjacent cells and lack interdigitations. The apical ends of these lateral walls of the adjacent cells join together by the junctional complexes (Figs. 31 and 32). Moreover, the basal cell membrane is extremely infolded and is in contact with the conspicuous basement membrane (Fig. 34).

\section{b- The enterocytes of the rectum}

The enterocytes are tall columnar cells (about $43 \mu \mathrm{m}$ in average height), which rest on the basement membrane. The apical cell membrane bears short, well-spaced and regularly arranged cytoplasmic projections, the microvilli, 
which form the brush border (Fig. 36). These microvilli are covered by the glycocalyx. The mean length of the microvilli is about $0.2 \mu \mathrm{m}$ and their mean diameter is about $0.15 \mu \mathrm{m}$. The apical cytoplasm, just below the microvilli, has no cellular organelles and forms the terminal web (Fig. 37).

The Golgi apparatus is well developed; it is found in a supranuclear position and is formed of one or more sets of numerous parallel stacks (Fig. 37).

The vesiculotubular system is well developed and is made up of numerous smooth vesicles and tubules with dense outlines. They are scattered throughout the cell cytoplasm, especially at the apical region (Fig. 37). The mean diameter of the vesicles is about $0.2 \mu \mathrm{m}$, while the mean diameter of the tubules is about $0.06 \mu \mathrm{m}$.

The rough endoplasmic reticulum consists of numerous long and parallel tubules, which are scattered in the cytoplasm and surround the nucleus. On the other hand, the smooth endoplasmic reticulum consists of smooth and wide tubules and cisternae (Fig. 37). The free ribosomes are abundant and scattered throughout the cell cytoplasm (Figs. 37 and 38).

The mitochondria are electron-dense, rounded or elongated in shape and have variable sizes (the mean diameter is about $0.6 \mu \mathrm{m}$ and the mean long axis is about $1.2 \mu \mathrm{m})$. The inner mitochondrial membrane forms numerous lamellar cristae (Fig. 39). They are scattered throughout the cell cytoplasm (Fig. 36) and are also aggregated in the basal regions of the enterocytes (Fig. 39).

The cytoplasm of the enterocyte is characterized by the presence of numerous lysosomes, which are surrounded by distinct membranes (Figs. 36 and 37).

The enterocyte contains numerous microtubules, which are scattered in the cytoplasm and run parallel to the lateral cell membrane (Fig. 38). The mean diameter of these microtubules is about $0.025 \mu \mathrm{m}(25 \mathrm{~nm})$.

The nucleus is oval in shape (the long axis is about $7 \mu \mathrm{m}$ ) and with a prominent nucleolus. The nuclear envelope is a double membrane consisting of the outer and inner nuclear membranes that encompass the nucleoplasm. The chromatin is represented mainly by the euchromatin, which is formed of the pale granular areas of the nucleoplasm. On the other hand, the heterochromatin is poorly developed and consists of small dark granular patches at the inner sides of the inner nuclear membrane (Fig. 40).

The lateral cell membranes form smooth contacts with the adjacent cells and lack interdigitations. The apical ends of these lateral cell membranes of the adjacent cells join together by the junctional complexes (Fig. 36).

\section{DISCUSSION}

The observations obtained from the present study indicate that the relative gut length of the herbivorous Labeo niloticus is longer than that of the carnivorous Schilbe mystus. These results agree with those of Grau et al. (1992), in Seriola dumerili, Petrinec et al. (2005), in Esox lucius and Silurus glanis, and 
Carrassón et al. (2006), in Dentex dentex, who stated that these carnivorous species possess a short gut. In addition, Elliott and Bellwood (2003) postulated that the corallivores, omnivores and herbivores possess the longest intestines, but the carnivores possess the shortest intestines. This concept was also postulated by German and Horn (2006), in the herbivorous Cebidichthys violaceus and the carnivorous Anoplarchus purpurescens, and Horn et al. (2006), in the herbivorous estuarine Atherinopsis affinis and the carnivorous Atherinopsis californiensis and Leuresthes tenuis.

Due to the lower digestive efficiency, the herbivorous Labeo niloticus is characterized by an extremely long gut to maximize the assimilation of the nutrients. This functional explanation agrees with that of Albrecht et al. (2001) in Leporinus friderici and Leporinus taeniofasciatus, who suggested that the long intestine of the herbivorous species is due to some components of the diet, which are slowly digested and require both a longer time and more extensive enzymatic exposure.

In Schilbe mystus, there is a prominent constriction, the pyloric sphincter, between the pyloric portion of the stomach and the intestine, which may serve to control the food passage into the duodenum. This result agrees with that of Weinreb and Bilstad (1955), in Salmo gairdneri irideus, Martin and Blaber (1984), in three Ambassis species, Ostos Garrido et al. (1996), in Anguilla anguilla, Albrecht et al. (2001), in Leporinus friderici and Leporinus taeniofasciatus, and Mai et al. (2005), in Pseudosciaena crocea.

The intestinal muscularis of both studied species is differentiated into two layers of unstriated muscle fibres: an inner circular layer and an outer longitudinal one. This finding agrees with that of Gargiulo et al. (1998), in Tilapia spp., and Albrecht et al. (2001), in Leporinus friderici and Leporinus taeniofasciatus. However, this result contradicts with that of Grau et al. (1992) who described three layers of unstriated muscle fibres throughout the whole intestinal length of Seriola dumerili.

The intestinal mucosa of both studied species is built up of two types of cells: the enterocytes and goblet cells. This result agrees with that of Cataldi et al. (1987), in Sparus aurata, and Gargiulo et al. (1998), in Tilapia spp. The enterocytes of the intestine of both studied species are tall columnar cells with numerous apical microvilli, forming the brush border, and are interconnected in the apical regions by the junctional complexes. These results agree with those of Olsen et al. (1999) in Salvelinus alpinus. Moreover, Kiliaan et al. (1996) suggested that the junctional complexes of the enterocytes of Carassius auratus may prevent the paracellular leak of ions and macromolecules. In addition, Zambonino Infante and Cahu (2001) reported that the intestinal brush border membranes of some marine teleosts are linked to enzymes, such as peptidases and disaccharidases, which lead to the total digestion of the diet components and allowing their absorption by the enterocytes. 
The height of the enterocyte microvilli, in both studied species, decreases from the anterior to the posterior region of the intestine. This result agrees with that of Kuperman and Kuz'mina (1994), in Esox lucius and Lota lota, who stated that the height of the microvilli is certainly dependent on the localization of the enterocytes in the different regions of the fish intestine. In addition, they reported that the maximal height of the enterocyte microvilli of these fishes is observed in the anterior region of the intestine.

The tips of some microvilli of the enterocytes of the anterior part of the intestine of both studied species possess blebs or capitula, which may increase the apical surface and intensify penetration. Similar results were reported by Kuperman and Kuz'mina (1994) in Esox lucius, Lota lota and Abramis brama.

The enterocytes of the anterior portion of the intestine of Schilbe mystus contain numerous large lipid droplets, while those of Labeo niloticus contain small chylomicron particles. These observations suggest that the enterocytes of the anterior portion of the intestine are involved in lipid absorption. This suggestion is in accordance with that of Stroband and Debets (1978), in Ctenopharyngodon idella, Anderson (1986), in Girella tricuspidata, Deplano et al. (1989), in Dicentrarchus labrax, Olsen et al. (1999), in Salvelinus alpinus, Gallagher et al. (2001), in Lagodon rhomboids, Caballero et al. (2003), in Sparus aurata, Kozarić et al. (2004), in Merluccius merluccius, and Carrassón et al. (2006), in Dentex dentex. Moreover, Fontagné et al. (1998), in Cyprinus carpio, stated that the intestinal fat droplets can be interpreted as a temporary storage form of the re-esterified fatty acids.

The enterocytes of the duodenum and ileum of Schilbe mystus have no endocytotic vesicles, while the enterocytes of the intestinal swelling and ileum of Labeo niloticus contain a few numbers of endocytotic channels. NoaillacDepeyre and Gas (1974 and 1976), in Cyprinus carpio and Tinca tinca, respectively, and Olsen et al. (1999), in Salvelinus alpinus, suggested that the endocytosis of lipid is not a major route of lipid absorption in the anterior intestine enterocytes. Moreover, Stroband and Debets (1978) stated that the anterior and middle segments of the intestine of the herbivorous Ctenopharyngodon idella possess endocytotic vesicles to uptake protein macromolecules.

The rectal mucosa of the carnivorous Schilbe mystus possesses numerous goblet cells amongst the enterocytes, while that of the herbivorous Labeo niloticus possesses a few numbers of goblet cells. numerous mucosal goblet cells were also found by Martin and Blaber (1984), in three carnivorous Ambassis species, and Grau et al. (1992), in the carnivorous Seriola dumerili. The farmer authors added that the mucus may serve as a lubrication aid to defecation. On the other hand, a few numbers of mucosal goblet cells were also reported by Girgis (1952) in the herbivorous Labeo horie.

The rectal muscularis of both studied species is thicker than that of the rest of the intestine. This result agrees with that of Grau et al. (1992) in Seriola 
dumerili, but contradicts with that of Gargiulo et al. (1998) who stated that the thickness of the rectal muscularis of Tilapia spp. is the same as the rest of the intestine.

The enterocytes of the rectum of Schilbe mystus possess endocytotic vesicles in the terminal web. This observation agrees with that of Deplano et al. (1989), in Dicentrarchus labrax, Olsen et al. (1999), in Salvelinus alpinus, Kozarić et al. (2004), in Merluccius merluccius, and Olsen et al. (2005), in Oncorhynchus mykiss, who stated that the presence of the endocytotic vesicles in the rectal enterocytes may be a complement to the luminal protein digestion by absorbing protein macromolecules. Moreover, Gargiulo et al. (1998), in Tilapia spp, suggested that the endocytosis is followed by the intracellular digestion by the lysosomes.

The rectal enterocytes of Labeo niloticus possess an extensive and a well-developed vesiculotubular system, which may be involved in ion transport. This observation agrees with that of Pack et al. (1996) in the stomachless Brachydanio rerio. In addition, the rectal enterocytes of Labeo niloticus have no prominent endocytotic vesicles. Stroband and Debets (1978) reported the same observation in the posterior segment of the intestine of the herbivorous Ctenopharyngodon idella.

The mucosa of the whole intestine of both studied species contains numerous lymphocytes, which may play a role in protecting the fish from pathogenic organisms. This result agrees with that of Osman and Caceci (1991), in Tilapia nilotica, and Park and Kim (2001), in Misgurnus mizolepis. Moreover, Temkin and McMillan (1986) stated that the gut of Carassius auratus lacks the discrete aggregations of lymphoid tissue, such as the Peyer's patches of mammals, but possesses a diffused lymphoid tissue as numerous lymphocytes.

\section{REFERENCES}

Albrecht, M.P.; Ferreira, M.F.N. and Caramaschi, E.P. (2001). Anatomical features and histology of the digestive tract of two related neotropical omnivorous fishes (Characiformes; Anostomidae). J. Fish Biol., 58: 419-430.

Al-Hussaini, A.H. (1947). The feeding habits and the morphology of the alimentary tract of some teleosts living in the neighbourhood of the marine biological station, Ghardaga, Red Sea. Pub. Mar. Biol. Stat., Ghardaga, Red Sea, 5: 1-61.

Anderson, T.A. (1986). Histological and cytological structure of the gastrointestinal tract of the luderick, Girella tricuspidata (Pisces, Kyphosidae), in relation to diet. J. Morph., 190: 109-119. 
Caballero, M.J.; Izquierdo, M.S.; Kjørsvik, E.; Montero, D.; Socorro, J.; Fernández, A.J. and Rosenlund, G. (2003). Morphological aspects of intestinal cells from gilthead seabream (Sparus aurata) fed diets containing different lipid sources. Aquaculture, 225: 325-340.

Caceci, T. and Hrubec, T.C. (1989). Ultrastructure of the digestive tube of the black mollie. Proc. Elect. Micro. Soc. Am., 47: 914-915.

Caceci, T. and Hrubec, T.C. (1990). Histology and ultrastructure of the gut of the black mollie (Poecilia spp.), a hybrid teleost. J. Morph., 204: 265280 .

Carrassón, M.; Grau, A.; Dopazo, L. R. and Crespo, S. (2006). A histological, histochemical and ultrastructural study of the digestive tract of Dentex dentex (Pisces, Sparidae). Histol. Histopathol., 21(6): 579-593.

Cataldi, E.; Cataudella, S.; Monaco, G.; Rossi, A. and Tancioni, L. (1987). A study of the histology and morphology of the digestive tract of the sea- bream, Sparus aurata. J. Fish Biol., 30: 135-145.

Cinar, K. and Senol, N. (2006). Histological and histochemical characterization of the mucosa of the digestive tract in flower fish (Pseudophoxinus antalyae). Anat. Histol. Embryol., 35(3): 147-151.

Deplano, M.; Connes, R.; Diaz, J.P. and Paris, J. (1989). Intestinal steatosis in the farm-reared sea bass Dicentrarchus labrax. Dis. Aquat. Org., 6: 121-130.

Elliott, J.P. and Bellwood, D.R. (2003). Alimentary tract morphology and diet in three coral reef fish families. J. Fish Biol., 63: 1598-1609.

Fontagné, S.; Geurden, I.; Escaffre, A.M. and Bergot, P. (1998). Histological changes induced by dietary phospholipids in intestine and liver of common carp (Cyprinus carpio L.) larvae. Aquaculture, 161: 213-223.

Gallagher, M.L.; Luczkovich, J.J. and Stellwag, E.J. (2001). Characterization of the ultrastructure of the gastrointestinal tract mucosa, stomach contents and liver enzyme activity of the pinfish during development. J. Fish Biol., 58: 1704- 1713. 
Gargiulo, A.M.; Ceccarelli, P.; Dall'Aglio, C. and Pedini, V. (1998). Histology and ultrastructure of the gut of the tilapia (Tilapia spp.), a hybrid teleost. Anat. Histol. Embryol., 27: 89-94.

German, D.P. and Horn, M.H. (2006). Gut length and mass in herbivorous and carnivorous prickleback fishes (Teleostei: Stichaeidae): Ontogenetic, dietary and phylogenetic effects. Mar. Biol., 148: 1123-1134.

Girgis, S. (1952). On the anatomy and histology of the alimentary tract of an herbivorous bottom-feeding cyprinoid fish, Labeo horie (Cuvier). J. Morphol., 90: 317-362.

Grau, A.; Crespo, S.; Sarasquete, M.C. and González De Canales, M.L. (1992). The digestive tract of the amberjack Seriola dumerili, Risso: a light and scanning electron microscope study. J. Fish Biol., 41: 287-303.

Horn, M.H.; Gawlicka, A.K. and German, D.P. (2006). Structure and function of the stomachless digestive system in three related species of New World silverside fishes (Atherinopsidae) representing herbivory, omnivory and carnivory. Mar. Biol., 149: 1237-1245.

Jilek, R. (1979). Intestinal histology of Dorosoma cepedianum. J. Fish Biol., 14: 125-126.

Kapoor, B.G.; Smit, H. and Verighina, I.A. (1975). The alimentary canal and digestion in teleosts. In: "Advances in Marine Biology", Vol. 13. F.S. Russell and M. Young (eds.). Academic Press, London, pp.109-239.

Kayanja, F.J.B; Maloiy, G.M.O. and Reite, O.B. (1975). The fine structure of the intestinal epithelium of Tilapia grahami. Anat. Anz., 138: 451-462.

Kiliaan, A.J.; Scholten, G.; Bijlsma, P.B.; Dekker, K. and Groot, J.A. (1996). Influence of forskolin and carbachol on intestinal absorption of horseradish peroxidase in the goldfish (Carassius auratus). Cell Tiss. Res., 285: 51-56.

Kozarić, Z.; Kužir, S.; Nejedli, S.; Petrinec, Z. and Srebočan, E. (2004). Histochemical distribution of digestive enzymes in hake, Merluccius merluccius L., 1758. Vet. Arhiv., 74(4): 299-308. 
Kuperman, B. I. and Kuz'mina, V. V. (1994). The ultrastructure of the intestinal epithelium in fishes with different types of feeding. J. Fish Biol., 44: 181-193.

MacDonald, N. L. (1987). An electron microscopic examination of the gastrointestinal epithelium of the Dover sole, Solea solea L. J. Fish Biol., 31: 27-36.

Mai, K.; Yu, H.; Ma, H.; Duan, Q.; Gisbert, E.; Zambonino Infante, J.L. and Cahu, C.L. (2005). A histological study on the development of the digestive system of Pseudosciaena crocea larvae and juveniles. J. Fish Biol., 67: 1094-1106.

Martin, T.J. and Blaber, S.J.M. (1984). Morphology and histology of the alimentary tract of Ambassidae (Cuvier) (Teleostei) in relation to feeding. J. Morph., 182: 295-305.

Noaillac-Depeyre, J. and Gas, N. (1974). Fat absorption by the enterocytes of the carp (Cyprinus carpio L.). Cell Tiss. Res., 155: 353-365.

Noaillac-Depeyre, J. and Gas, N. (1976). Electron microscopic study on gut epithelium of the tench (Tinca tinca L.) with respect to its absorptive functions. Tiss. Cell, 8: 511-530.

Noaillac-Depeyre, J. and Gas, N. (1979). Structure and function of the intestinal epithelial cells in the perch (Perca fluviatilis L.). Anat. Rec., 195: 621639.

Olsen, R.E.; Myklebust, R.; Kaino,T. and Ringø, E. (1999). Lipid digestibility and ultrastructural changes in the enterocytes of Arctic char (Salvelinus alpinus L.) fed linseed oil and soybean lecithin. Fish Physiol. Biochem., 21: 35-44.

Olsen, R.E.; Sundell, K.; Mayhew, T.M.; Myklebust, R. and Ringø, E. (2005). Acute stress alters intestinal function of rainbow trout Oncorhynchus mykiss (Walbaum). Aquaculture, 250: 480-495. 
Osman, A.H.K. and Caceci, T. (1991). Histology of the stomach of Tilapia nilotica (Linnaeus, 1758) from the River Nile. J. Fish Biol., 38: 211223.

Ostos Garrido, M.V.; González Oller, C. and Abaurrea Equisoain, M.A. (1996). Effect of diet on gastric mucosa cells in the European eel (Anguilla anguilla L.). Histochemical and ultrastructural study. Micron, 27(1): 25-34.

Pack, M.; Solnica-Krezel, L.; Malicki, J.; Neuhauss, S.C.F.; Schier, A.F.; Stemple, D.L.; Driever, W. and Fishman, M. C. (1996). Mutations affecting development of zebrafish digestive organs. Development, 123: 321-328.

Park, J.Y. and Kim, I.S. (2001). Histology and mucin histochemistry of the gastrointestinal tract of the mud loach, in relation to respiration. J. Fish Biol. 58: 861-872.

Petrinec, Z.; Nejedli, S.; Kužir, S. and Opačak, A. (2005). Mucosubstances of the digestive tract mucosa in northern pike (Esox lucius L.) and European catfish (Silurus glanis L.). Vet. Arhiv., 75(4): 317-327.

Reynolds, E. S. (1963). The use of lead citrate at high $\mathrm{pH}$ as an electron opaque stain in electron microscopy. J. Cell Biol., 17: 208-212.

Stroband, H.W.J. (1977). Growth and diet dependent structural adaptations of the digestive tract in juvenile grass carp (Ctenopharyngodon idella, Val.). J. Fish Biol., 11: 167-174.

Stroband, H.W.J. and Debets, F.M.H. (1978). The ultrastructure and renewal of the intestinal epithelium of the Juvenile grasscarp, Ctenopharyngodon idella (Val.). Cell Tiss. Res., 187: 181-200.

Temkin, R.J. and McMillan, D.B. (1986). Gut-associated lymphoid tissue (GALT) of the goldfish, Carassius auratus. J. Morphol., 190: 9-26.

Tibbetts, I.R. (1997). The distribution and function of mucous cells and their secretions in the alimentary tract of Arrhamphus sclerolepis krefftii. J. Fish Biol., 50: 809-820. 
Ünal, G.; Çetinkaya, O.; Kankaya, E. and Elp, M. (2001). Histological study of the organogenesis of the digestive system and swim bladder of the Chalcalburnus tarichi Pallas, 1811 (Cyprinidae). Turk. J. Zool., 25: 217-228.

Watanabe, Y. (1981). Ingestion of horse-radish peroxidase by intestinal cells in larvae or juveniles of some teleosts. Bull. Jap. Soc. Sci. Fish., 47: 1299-1307.

Weinreb, E.L. and Bilstad, N.M. (1955). Histology of the digestive tract and adjacent structures of the rainbow trout, Salmo gairdneri irideus. Copeia, 3: 194-204.

Yamamoto, T. (1966). An electron microscope study of the columnar epithelial cells in the intestine of fresh water teleost: gold fish (Carassius auratus) and rainbow trout (Salmo irideus). Z. Zellforsch., 72: 66-87.

Zambonino Infante, J.L. and Cahu, C.L. (2001). Ontogeny of the gastrointestinal tract of marine fish larvae. Comp. Biochem. Physiol., part (C): Toxicol. Pharmacol., 130(4): 477-487. 


\section{EXPLANATION OF FIGURES}

Fig. (1): Photomicrograph of T. S. of the duodenum of Schilbe mystus showing the mucosa, submucosa, muscularis, serosa and villi. H \& E stain, X 45.

Fig. (2): Photomicrograph of T. S. of the duodenum of Schilbe mystus showing the mucosal epithelial cells, goblet cells, brush border, lamina propria and submucosa. PAS \& H stain, X 485.

Fig. (3): Photomicrograph of T. S. of the duodenum of Schilbe mystus showing the villi, mucosal epithelial cells, lymphocytes, brush border, basement membrane, lamina propria and submucosa. H \& E stain, X 450.

Fig. (4): Photomicrograph of a semithin section of the duodenum of Schilbe mystus showing the apical parts of the mucosal epithelial cells with lipid droplets and brush border and goblet cells. Toluidine blue stain, X 1340 .

Fig. (5): Photomicrograph of a semithin section of the duodenum of Schilbe mystus showing the submucosa, muscularis, serosa circular muscle layer and longitudinal muscle layer. Toluidine blue stain, X 1210.

Fig. (6): Photomicrograph of T. S. of the ileum of Schilbe mystus showing the mucosa, submucosa, muscularis, serosa, villi and lamina propria. H \& E stain, X 180 .

Fig. (7): Photomicrograph of a semithin section of the ileum of Schilbe mystus showing the mucosal epithelial cells with lipid droplets and brush border, goblet cells, basement membrane and lamina propria. Toluidine blue stain, X 1290.

Fig. (8): Photomicrograph of a semithin section of the ileum of Schilbe mystus showing the muscularis with circular and longitudinal muscle layers. Toluidine blue stain, X 1350.

Fig. (9): Photomicrograph of T. S. of the rectum of Schilbe mystus showing the mucosa, submucosa, muscularis, serosa, villi, goblet cells, lamina propria, circular muscle layer and longitudinal muscle layer. H \& E stain, X 190.

Fig. (10): Enlarged portion of Fig. (9) showing the mucosa, submucosa, villi, mucosal epithelial cells, goblet cells, lymphocytes, brush border, basement membrane and lamina propria. H \& E stain, X 490. 
Fig. (11): Photomicrograph of T. S. of the anterior part of the ileum of Labeo niloticus showing the mucosa, submucosa, muscularis, serosa, villi, goblet cells, brush border, lamina propria, blood vessels, circular muscle layer and longitudinal muscle layer. H \& E stain, X 200.

Fig. (12): Photomicrograph of T. S. of the posterior part of the ileum of Labeo niloticus showing the mucosa, submucosa, muscularis, serosa, villi, goblet cells, lamina propria, blood vessels, circular muscle layer and longitudinal muscle layer. H \& E stain, X 190.

Fig. (13): Photomicrograph of L. S. of the ileum of Labeo niloticus showing the mucosal epithelial cells, goblet cells, lymphocytes, basement membrane and lamina propria. H \& E stain, X 1360.

Fig. (14): Photomicrograph of T. S. of the rectum of Labeo niloticus showing the mucosa, submucosa, muscularis, serosa, villi, lamina propria, circular muscle layer and longitudinal muscle layer. H \& E stain, X 110.

Fig. (15): Enlarged portion of Fig. (14) showing the mucosal epithelial cells, goblet cell, lymphocytes, brush border, basement membrane and lamina propria. H \& E stain, X 1270.

Fig. (16): Photomicrograph of a semithin section of the rectum of Labeo niloticus showing the submucosa, muscularis, serosa, basement membrane, circular muscle layer and longitudinal muscle layer. Toluidine blue stain, X 1150 .

Fig. (17): Electron micrograph of the duodenal mucosa of Schilbe mystus showing the enterocytes, microvilli, terminal web, junctional complexes and lipid droplets.

Fig. (18): Electron micrograph of the duodenal enterocytes of Schilbe mystus showing the Golgi apparatus, free ribosomes and nucleus.

Fig. (19): Electron micrograph of the duodenal enterocytes of Schilbe mystus showing the lipid droplets, rough endoplasmic reticulum and mitochondria.

Fig. (20): Electron micrograph of the duodenal enterocytes of Schilbe mystus showing the microtubules, nucleus, euchromatin, heterochromatin, nuclear envelope and nuclear pore. 
Fig. (21): Electron micrograph of the duodenal enterocytes of Schilbe mystus showing the lipid droplets, nucleus, nucleolus, euchromatin, heterochromatin, nuclear envelope and nuclear pore.

Fig. (22): Electron micrograph of the mucosa of the ileum of Schilbe mystus showing the enterocytes, goblet cell, microvilli, terminal web, mitochondria, lipid droplets, nucleus and nucleolus.

Fig. (23): Electron micrograph of the mucosa of the ileum of Schilbe mystus showing the apical parts of the enterocytes, microvilli, capitulum, terminal web, junctional complex, rough endoplasmic reticulum and mitochondria.

Fig. (24): Electron micrograph of the enterocytes of the ileum of Schilbe mystus showing the Golgi apparatus, free ribosomes and smooth endoplasmic reticulum.

Fig. (25): Electron micrograph of the enterocytes of the ileum of Schilbe mystus showing the rough endoplasmic reticulum, free ribosomes and mitochondria.

Fig. (26): Electron micrograph of the enterocytes of the ileum of Schilbe mystus showing the microtubules, nucleus, nucleolus, euchromatin, heterochromatin, nuclear envelope and nuclear pore.

Fig. (27): Electron micrograph of the rectal mucosa of Schilbe mystus showing the enterocytes, goblet cells, microvilli, terminal web, junctional complex, mitochondria, nucleus and nucleolus.

Fig. (28): Electron micrograph of the apical parts of the rectal enterocytes of Schilbe mystus showing the microvilli, capitulum, terminal web, endocytotic vesicles, vesiculotubular system and microfilaments.

Fig. (29): Electron micrograph of the rectal enterocyte of Schilbe mystus showing the Golgi apparatus, rough and smooth endoplasmic reticula, free ribosomes, nucleus, euchromatin, heterochromatin and nuclear envelope.

Fig. (30): Electron micrograph of the rectal enterocyte of Schilbe mystus showing the microtubules, microfilaments, rough endoplasmic reticulum, free ribosomes, lysosomes and mitochondria. 
Fig. (31): Electron micrograph of the mucosa of the ileum of Labeo niloticus showing the enterocytes, goblet cell, microvilli, terminal web, junctional complexes, lysosomes, nucleus and nucleolus.

Fig. (32): Electron micrograph of the mucosa of the ileum of Labeo niloticus showing the apical parts of the enterocytes, microvilli, capitulum, terminal web, endocytotic channel, smooth endoplasmic reticulum, junctional complex, lysosomes and mitochondria.

Fig. (33): Electron micrograph of the enterocytes of the ileum of Labeo niloticus showing the chylomicrons, Golgi apparatus, rough endoplasmic reticulum, free ribosomes microtubules, lateral cell membrane and nucleus.

Fig. (34): Electron micrograph of the basal parts of the enterocytes of the ileum of Labeo niloticus showing the mitochondria, basal cell membrane and basement membrane.

Fig. (35): Electron micrograph of the enterocytes of the ileum of Labeo niloticus showing the nucleus, euchromatin, heterochromatin, nuclear envelope, nuclear pore, rough endoplasmic reticulum and microtubules.

Fig. (36): Electron micrograph of the rectal mucosa of Labeo niloticus showing the enterocytes, microvilli, junctional complexes, mitochondria and lysosomes.

Fig. (37): Electron micrograph of the rectal enterocytes of Labeo niloticus showing the microvilli, terminal web, Golgi apparatus, rough and smooth endoplasmic reticula, free ribosomes, vesiculotubular system, mitochondria, lysosomes, nucleus and nucleolus.

Fig. (38): Electron micrograph of the rectal enterocytes of Labeo niloticus showing the free ribosomes, microtubules and vesiculotubular system.

Fig. (39): Electron micrograph of the rectal enterocytes of Labeo niloticus showing the mitochondria, vesiculotubular system, basal cell membrane and basement membrane.

Fig. (40): Electron micrograph of the rectal enterocytes of Labeo niloticus showing the nuclei, nucleoli, euchromatin, heterochromatin, nuclear envelopes, nuclear pore and mitochondria. 
Ba.mb

Bas.ce.mb

Bl.v

Br.bo

C.m.lr

Cap

Chy

Ec

Enc.ch

Enc.ves

Ent

Fr.rb

G.ce

Go.ap

$\mathrm{Hc}$

Jn.comp

L.m.lr

La.pr

Lat.ce.mb

Lp.dr

Ls

Ly

Mifi

Mit

Mivi

$\mathrm{Mt}$

Muc

Muc.ep.ce

Mus

$\mathrm{N}$

N.env

N.po

$\mathrm{Nu}$

R.e.r

S.e.r

Ser

Sm

Te.w

$\mathrm{Vi}$

Vt.sy

\section{LIST OF ABBREVIATIONS}

Basement membrane.

Basal cell membrane.

Blood vessel.

Brush border.

Circular muscle layer.

Capitulum.

Chylomicrons.

Euchromatin.

Endocytotic channel

Endocytotic vesicles.

Enterocyte.

Free ribosomes.

Goblet cell.

Golgi apparatus.

Heterochromatin.

Junctional complex.

Longitudinal muscle layer.

Lamina propria.

Lateral cell membrane.

Lipid droplet.

Lysosomes.

Lymphocyte.

Microfilaments.

Microtubules.

Microvilli.

Mitochondria.

Mucosa.

Mucosal epithelial cells.

Muscularis.

Nucleus.

Nuclear envelope.

Nuclear pore.

Nucleolus.

Rough endoplasmic reticulum.

Smooth endoplasmic reticulum.

Serosa.

Submucosa.

Terminal web.

Villi.

Vesiculotubular system. 

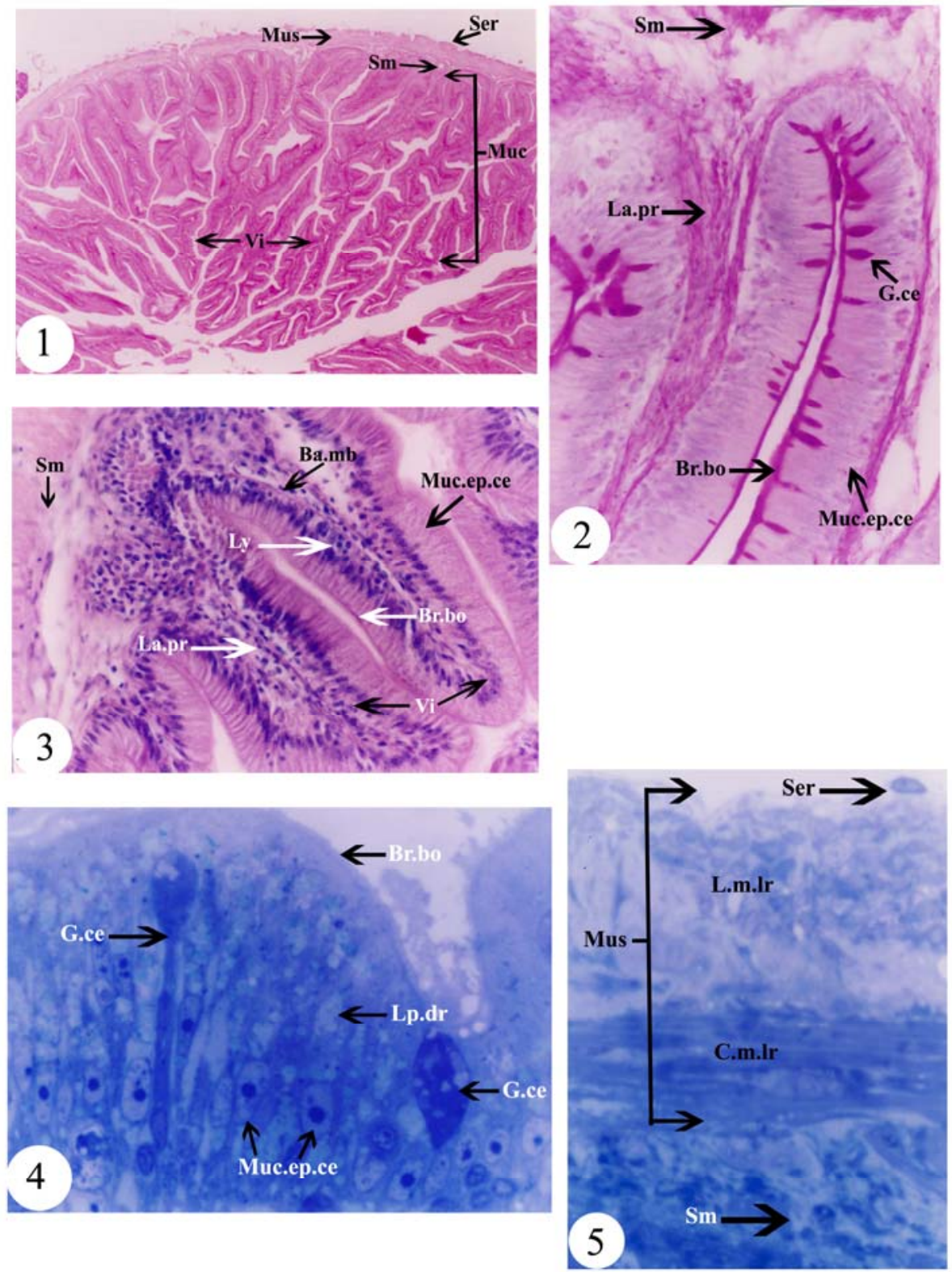

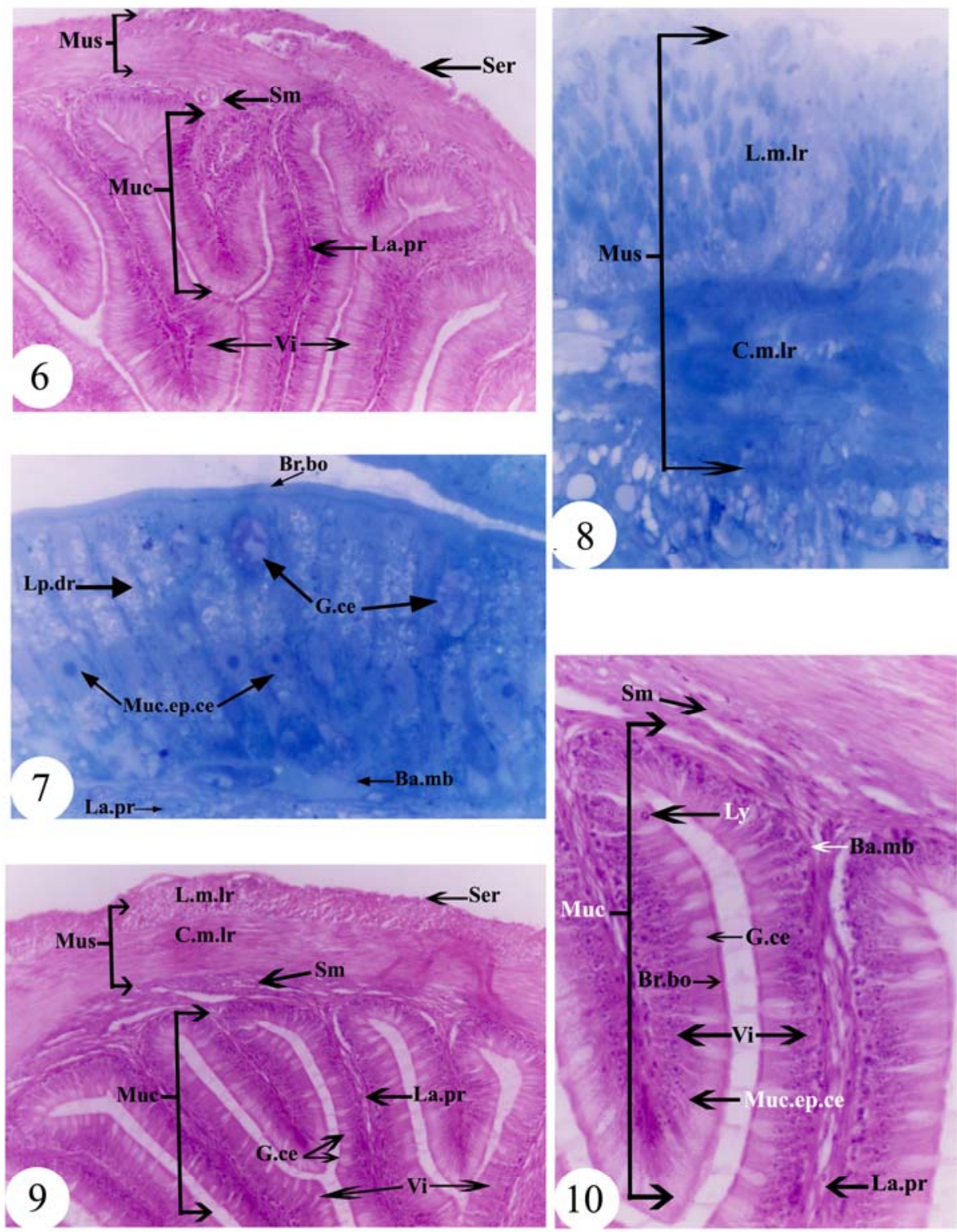


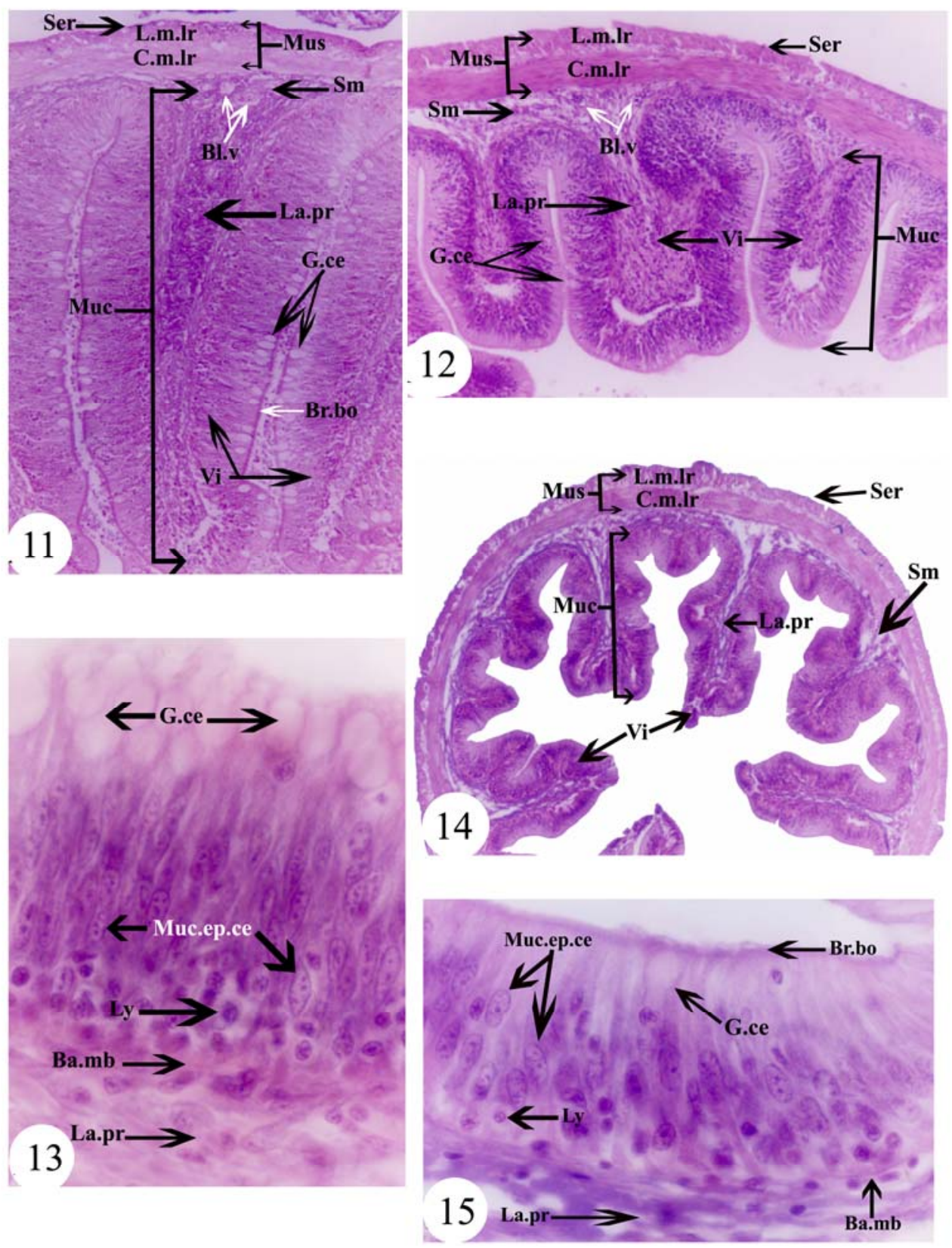



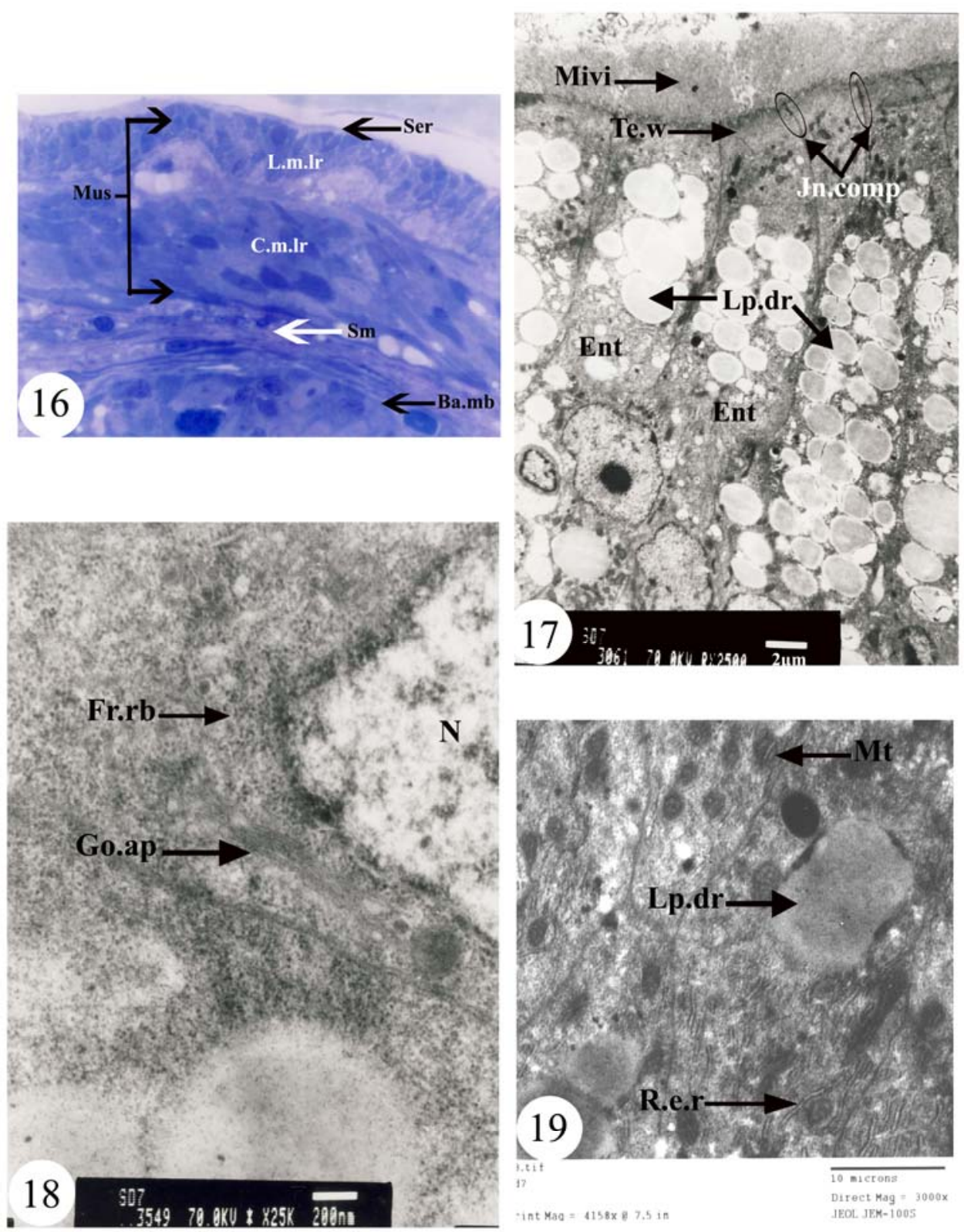

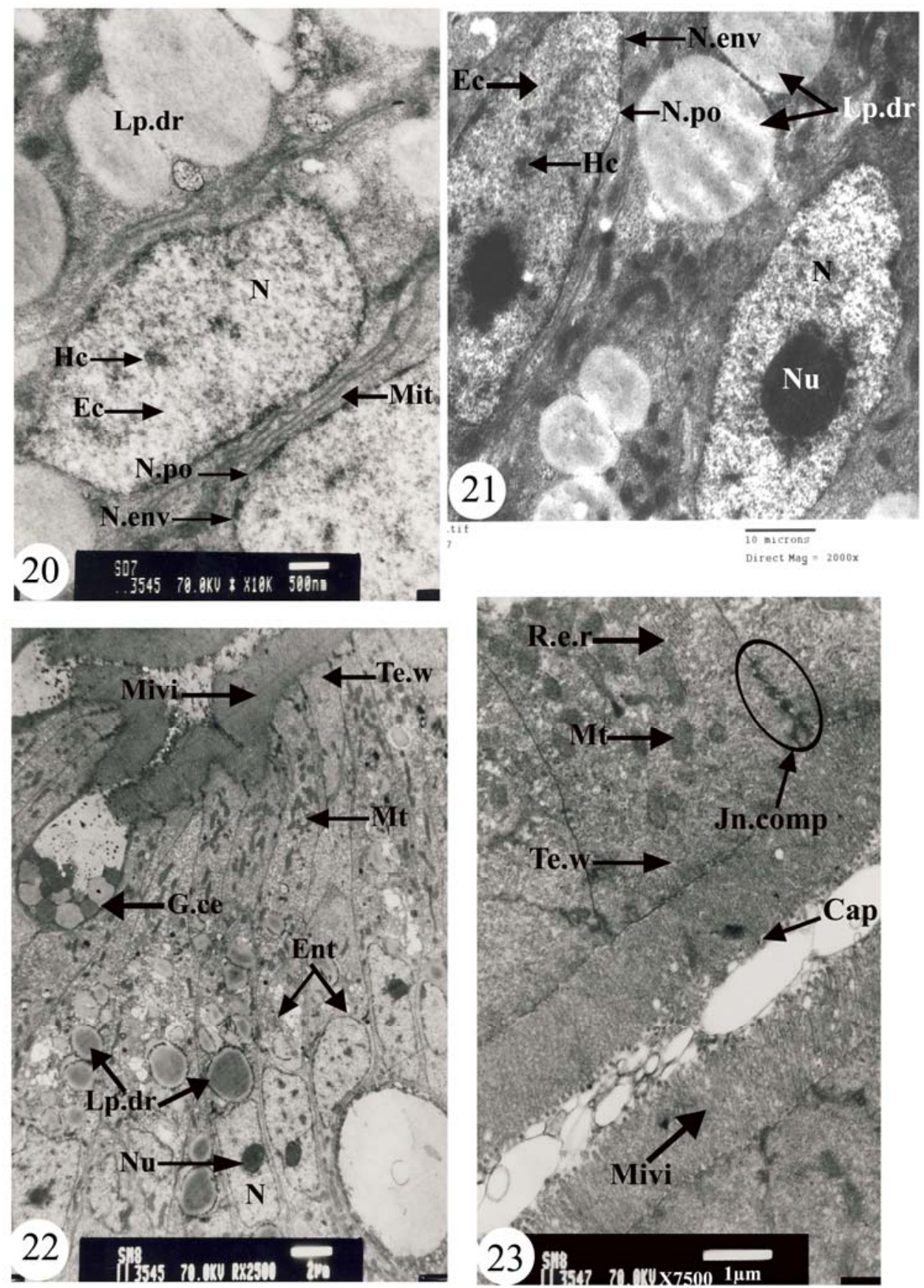

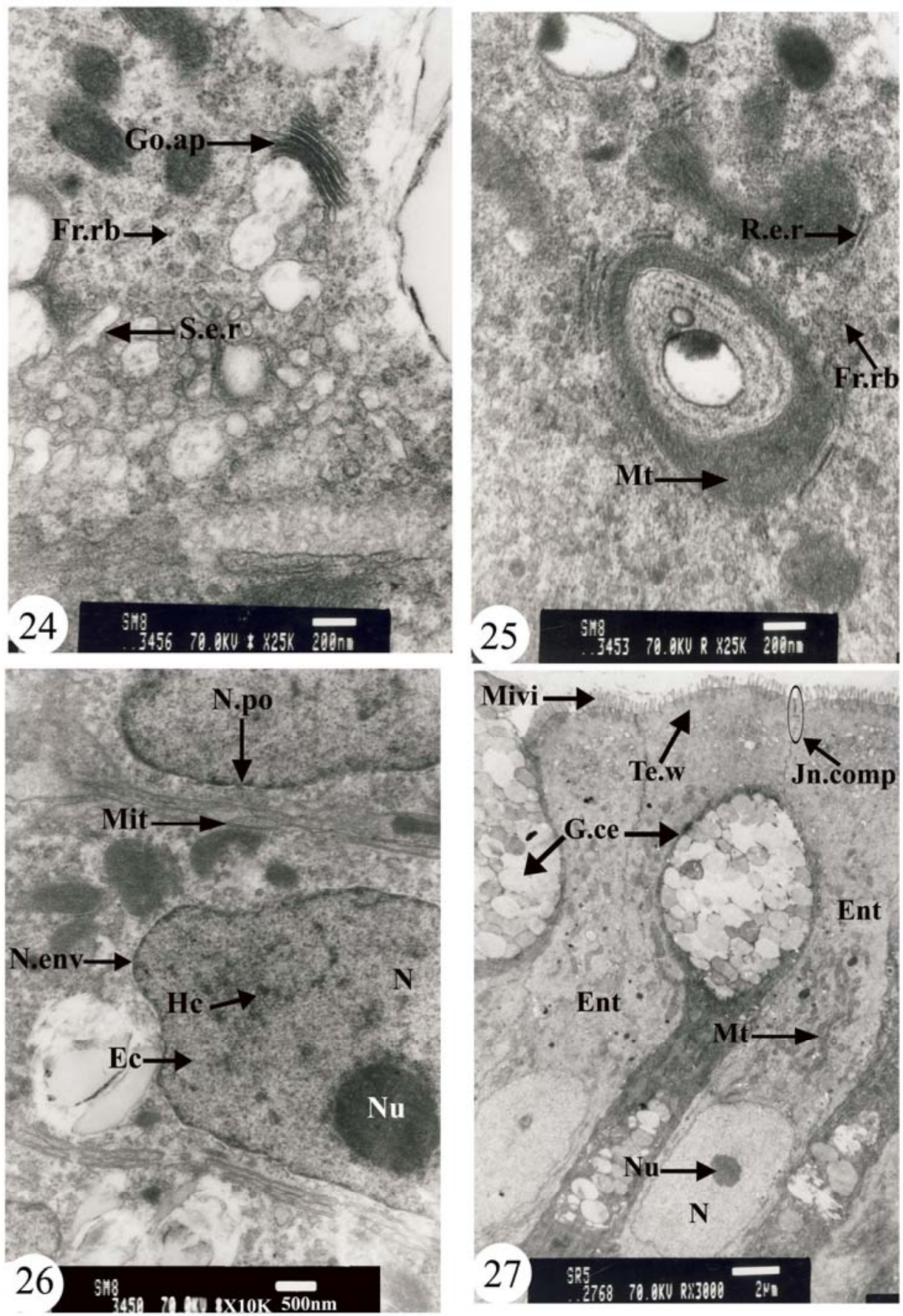

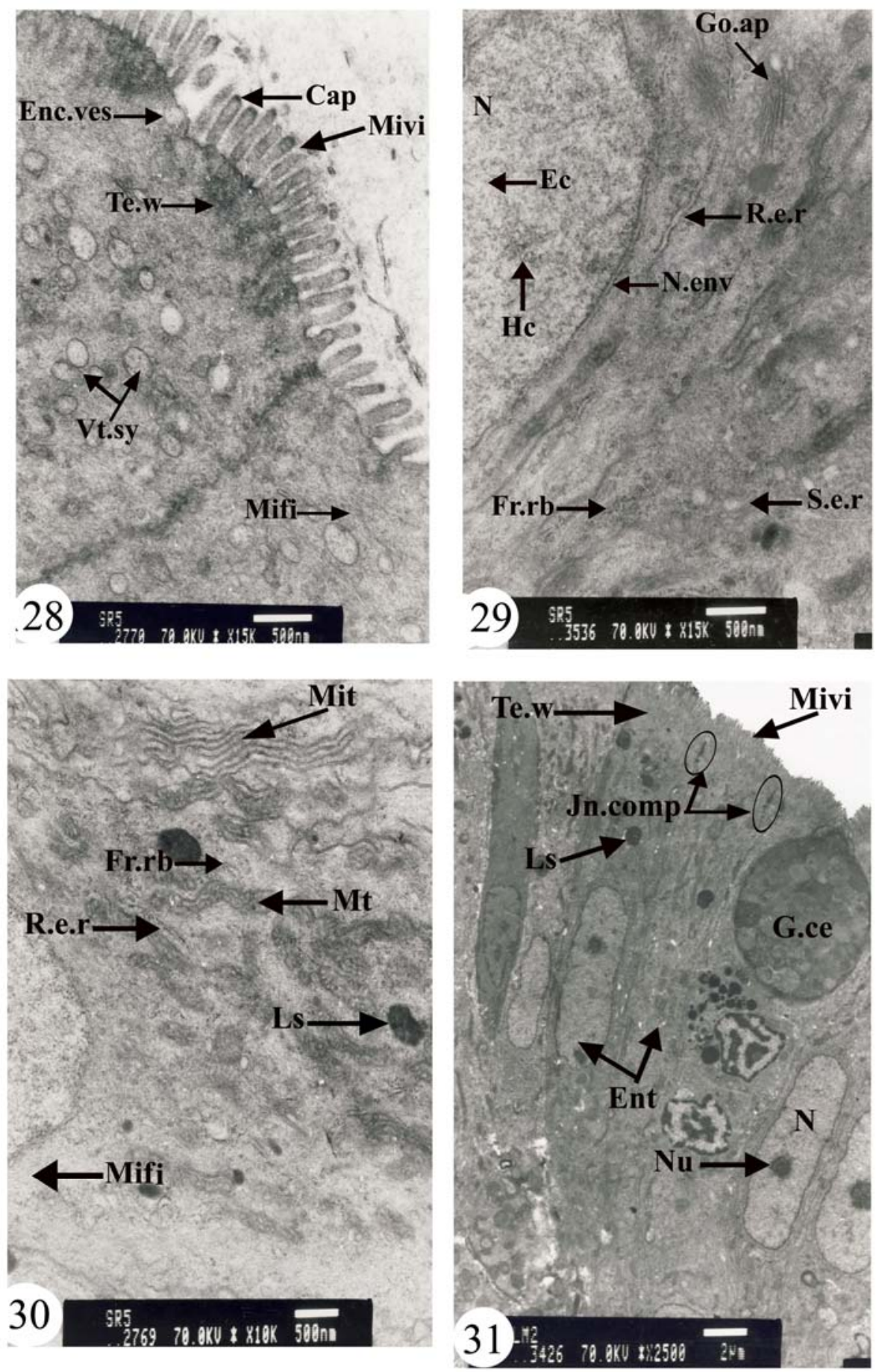

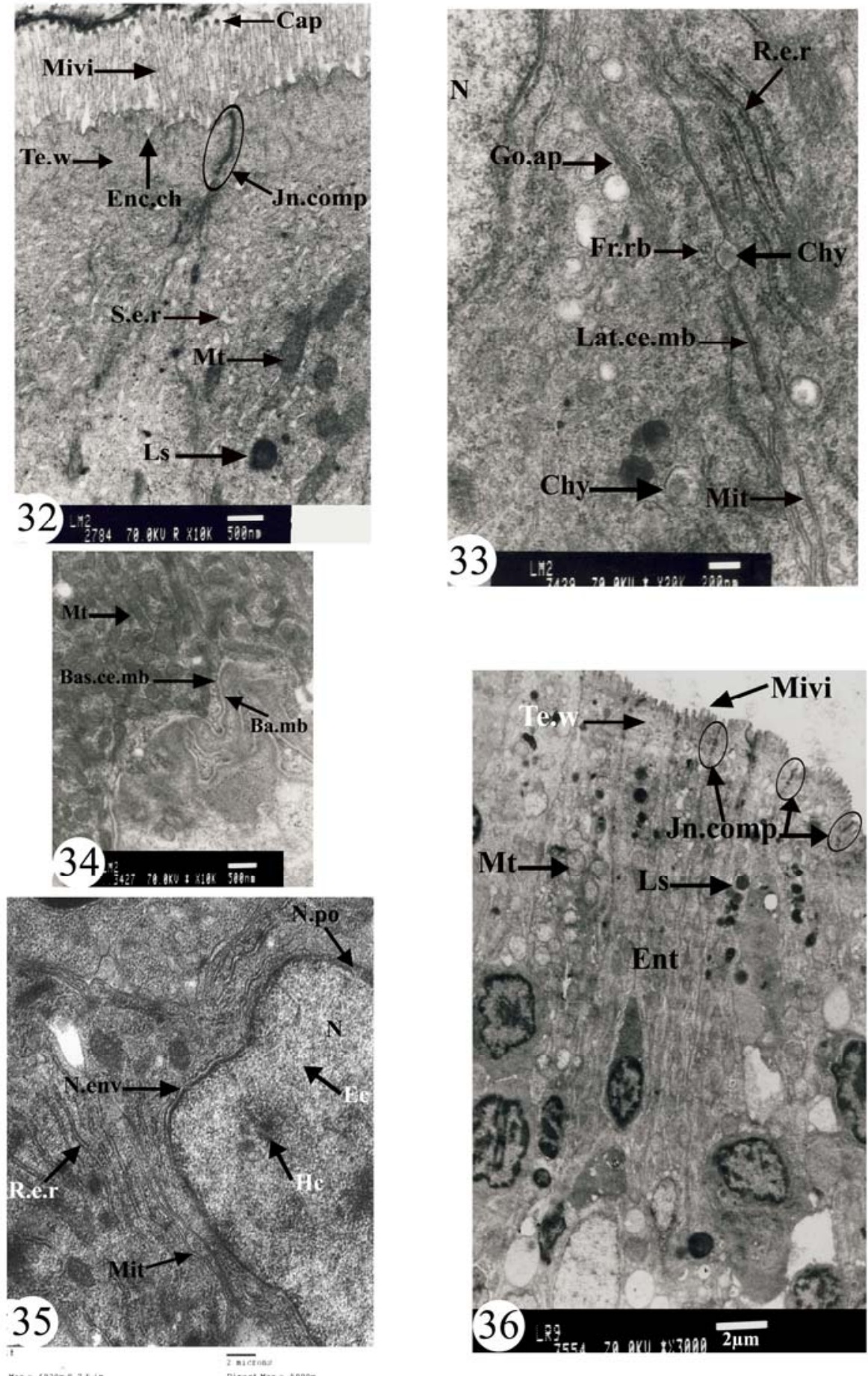

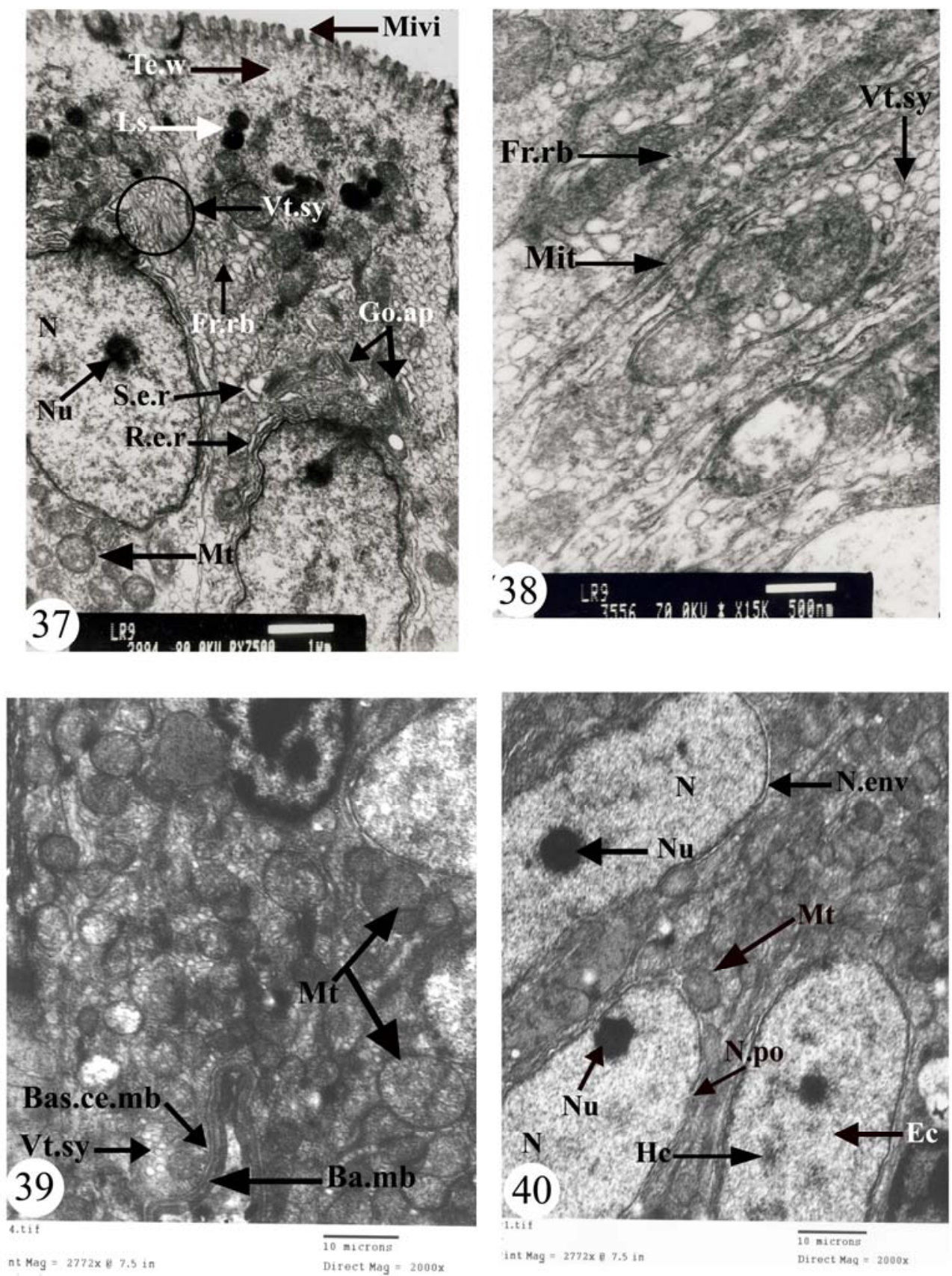